\title{
The US American Self-criticism. \\ Stories of Anger and Bewilderment
}

Montserrat Huguet

Universidad

Carlos III de Madrid 

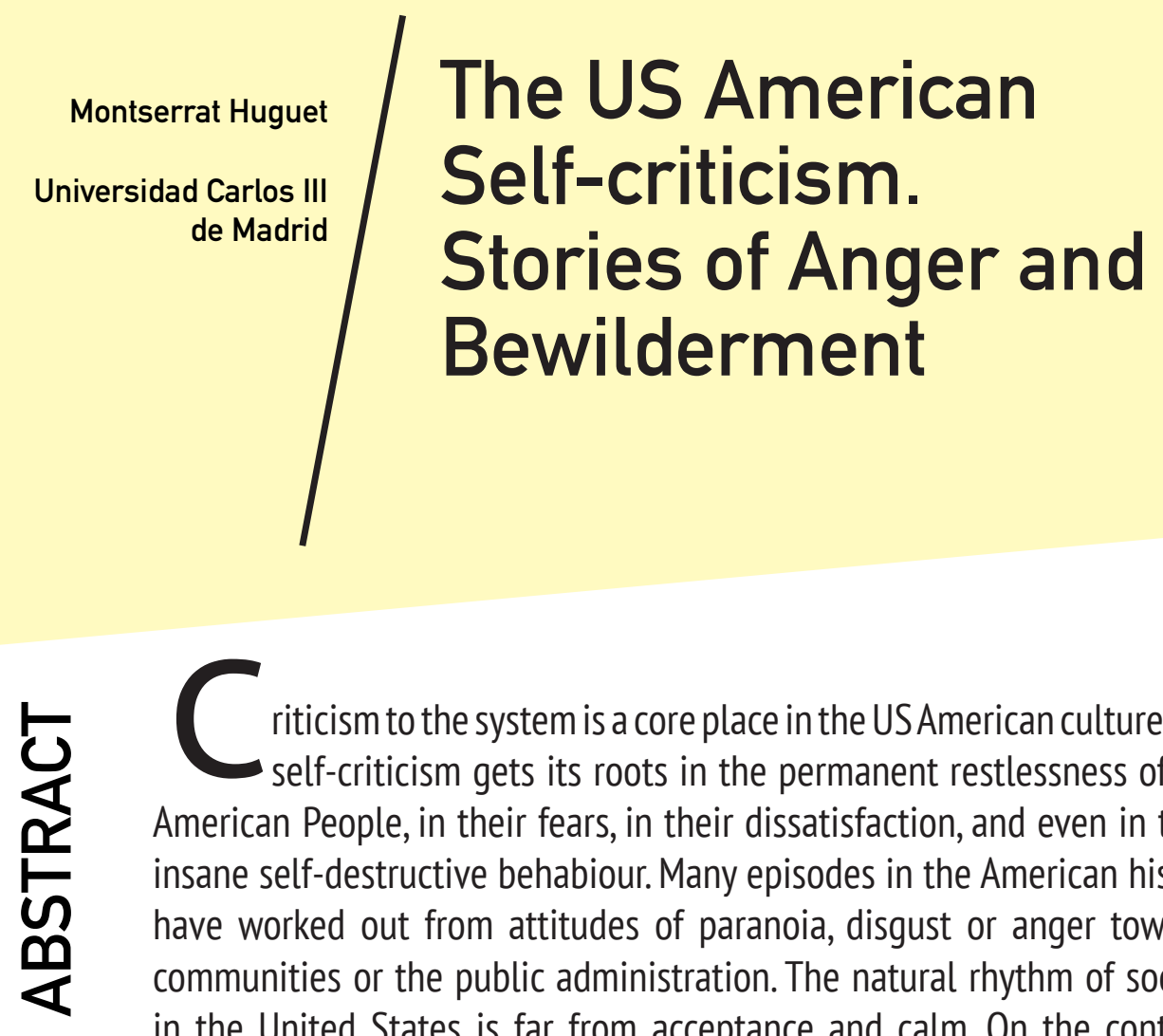

riticism to the system is a core place in the USAmerican culture.The self-criticism gets its roots in the permanent restlessness of the American People, in their fears, in their dissatisfaction, and even in their insane self-destructive behabiour. Many episodes in the American history have worked out from attitudes of paranoia, disgust or anger towards communities or the public administration. The natural rhythm of society in the United States is far from acceptance and calm. On the contrary, the US history is defined by restlessnees and doubious sentiments. Thus, one might think that the American dream is fundamentally a state of permanent crisis in which people, unable to deal with their present vital conditions, transmute these conditions into havoc and creation. In the pages of this article, a breaf tour into the historical and cultural trend of discouragement is offered. It also pays attention to the American ability to self-analyze its own historical experiences. The fictionated stories, that come from the imagination but also from people's voices and memories, convey a sense of dissatisfaction and of struggle to improve the American way of behaving. Those citizens, especially uncomfortable with themselves or with the administration, may not be aware that they are precisely those who constitute the best US image abroad. In the ostentation of a selfcriticism, of a subversive thought, these Americans, opposed to the official positions, feature the virtue of the relentless self-purge. Therefore, looking at past and present times, this paper is composed by six related arguments 
that rely on both historical events and fictionated stories, with the titles of: "Under the paranoid style"; "The angry nation", "Hate: Public Limited Company" "Images of anger", "Guilty, ashamed and redeemed", and "The legacy of disenchantment".

Key Words: United States, history, stories, culture, disenchantment, anger

\section{UNDER THE PARANOID STYLE}

In the mid-sixties Harper's Magazine published an article by Richard Hofstadter with the suggestive title of "The Paranoid Style in American Politics". At this point, in the $21^{\text {st }}$ century, we could think that nothing told by Hofstadter would call our attention. We perfectly know how McCarthyism worked in the fifties and how the Cold War acquired, in its ideological dimension, a toxic conspiratorial tone that permeated and decomposed American society. However, it is useful to re-read Hofstadter's text, since it helps to recover

\section{American politics had always been acted as theater scene for angry minds -mainly those very conservative groups who take their anger to the extreme of paranoid style.}

certain aspects that seemed non important at the time of its first edition but that nowadays would certainly acquire some relevance. Hofstadter stressed that American politics had always been acted as theater scene for angry minds - mainly those very conservative groups who take their anger to the extreme of paranoid style.

Long before McCarthyism, the political decisions of the administrations attended to this paranoid feeling. The permanent sensation of territorial vulnerability in the first decades of the 19th century favored the growth of the Navy, the building of coastal bastions or the trade agreements that helped to protect the American ships in the Mediterranean Sea from Berber piracy. The slave riots and run aways from the plantations also increased paranoia. White people in the slave states were afraid of the possibility of being slaughtered by a slave at any time while they were sleeping. In the emerging Midwest -the old Spanish Louisiana- soldiers and entrepreneurs felt behind them the shadow of the Indians. Fear of the unknown in the nineteenth century took the form of the runaway masses of Irish migrants: Papists who spoke Gaelic and were meant to ruin the precious American democracy through the devilish alliance with the Vatican. There was a broad record of circumstances that caused fear and, consequently, political decisions inspired by a paranoid worldview. 


\section{Fear of the unknown in} the nineteenth century took the form of the runaway masses of Irish migrants: Papists who spoke Gaelic and were meant to ruin

the precious American democracy. 
In the aforementioned Hofstadter paper several cases of the early American paranoid reaction are collected, such as the popular hostility towards the Illuminati and the Masons since the 1820 s, or towards the Catholics since the 1830s, with the massive images of aberration and hate. In relation to the panic caused by the alleged subversive actions of the Bavarian Illuminati -linked in America with the French Revolution and with a such bad press in the young republic-, it is to be highlighted that these Illuminati had developed a significant rationalist and anticlerical illustration due to the German Adam Weishaupt in the United States (1776). At the end of the century the Illuminati approached the Freemasons to outline their society model: a highly rational utopia. The text that influenced popular hostility the most towards enlightenment was written and published in 1797 in Edinburgh by John Robison, under the title of "Proofs of a Conspiracy Against All the Religions and Governmets of Europe, Carried on in the Secret Meetings of Free Mason, Illuminati, and Reading Societies".

Thus, the clergy felt very concerned as they realized that the Enlightment and the Freemasonry was a full-blown attack to the sources of Protestantism. But hostility towards these trends happened essentially in New England, among the most conservative sectors. From the pulpits and newspapers, Jeffersonian democracy was pointed out as a vehicle for these "anti-Christian" ideas; in the background, the conflict between the Jeffersonians (proFrench) and the Federalists (pro-British), the later being accused of radical Jacobinism by the President. Was the United States being the victim of an international plot supported by the Illuminati,Jacobins, and Jeffersonians? This issue already refers to a feeling of a clear paranoid sign that accuses a political trend of treason to the interests of the nation. And it is that in the twenties and thirties of the nineteenth century, the United States would live an authentic conspiracy mania that could be noticed in the popular classes -these voting segment expanded during the Jacksonian Democracy-, especially in rural areas. The anti-freemasons were also hostile to the restraint of opportunities for ordinary people or to the "aristocratization" of public life. Despite the strength of Freemasonry in the stage of setting up, it was understood that Freemasonry conspired against the essences of the Republic. Freemasons created a system of government in parallel to everyone's system: drawing among its members a loyalty outside the federal system and the states. Seen this way, behaving like a Mason was meant to be punished. So the street claimed jail and death penalty for the freemasons. The anti-Masonic defined Masonry as the most abominable and dangerous institution the humanity had ever known: a "Hell's Master Piece".

Catholics stood above the freemasons in their status as traitors to democracy. The supposed plot of Catholics against American values began its journey in the thirties popular mentality and anti-Catholicism eventually became a way of understanding the nation, linked of course to the general hostility against the waves of Catholic immigrants 
-Irish- in the central decades of the 19th century. In 1835 two books argued that a "new" danger against the American way of life had arisen, Morse's Foreign Conspiracies against the Liberties of the United States, and Lyman Beecher's Plea for the West. Morse was none but the inventor of the telegraph and in his book he claimed that there was a conspiracy that couldn't be defended by the country's ships or armies. Morse said that the aforementioned conspiracy came from the Catholic and Austrian government of Metternich, which launched its Jesuit missionaries across the ocean to infiltrate and destroy American society. Lyman Beecher, Harriet Beecher Stowe's father, said in Plea for the West that Protestantism was engaged in a life-and-death war with Catholicism. The aggression, also in this case, seemed

\section{Lyman Beecher, Harriet Beecher Stowe's father, said in Plea for the West that Protestantism was engaged in a life-and-death war with Catholicism.}

to come from Europe, as this continent sent a myriad of Catholics to the US in order to undermine its republic and its strength. The migrants brought violence and populated the prisons, obtained the resources for the local poor and, being so many, controlled the vote in some areas. In the stories of these and other authors, the morbid images were surprising. Priests and nuns were described as villains, licentious and murderers; there was even talk about debauchery in convents and monasteries, or about the public danger that one and the other represented for communities of goodness. On the cusp of paranoia, in 1836 the nun María Monk published Awful Disclosures, a kind of autobiography about the author's libertine and criminal life. This chapter of the 19th century paranoias can be closed without concluding. And things would not improve in the twentieth century, when people were frightened by a whole string of fears that had black people as agents, outsiders or foreigners with their large families and their contagious diseases, socialists, or even the cosmopolitan Americans, some of them called themselves 'pacifists'. Also women with voice, vote, literate and with a paid livelihood. It was interpreted that each of these subjects was a "strange" body in the perfect anatomy of the Republic. 
The American culture intend to mean: "we have not been defeated but betrayed". The perversion that arises from the thinking -unfounded and paranoid- that things are perverted because of betrayal has caused memorable excesses in the history of American power. However, it has also made visible the struggle of those who are hypothetically guilty of treason for wanting to disassemble "the system". A recent book, If This Be Treason: The American Rogues and Rebels Who Walked the Line Bettween Dissent and Betrayal, shows the effects on history of the thin line between the lack of affection towards the prevailing code and betrayal (Duda). Dissent can be treason, or not. This duel for the honest America is very delicate, a traditional matter of controversy that has been perfectly reflected in the fiction stories (Coale).

The Book of Daniel by E. L. Doctorow, whose release in 1971, coincided with a stage of hopelessness and turbulence in American society, shows the reader the fictional adventures of a central character within a plot that might be pure history (Jeong). Daniel Isaacson is a young man, son of a couple executed in the postwar period on charges of conspiracy to spy on the government and having passed sensitive information to the USSR. It is easy to find out in this plot the reference to the case of the Rosenbergs (Clune), the married couple executed by the federal government in 1953. Through his own experience, Daniel runs into a whole cast of characters coming from a frightened and paranoid society. He faces the critical questions of what it is to be a good American or if a citizen can be a patriot being disloyal to the administration. May be an Alter Ego of Isacson, Doctorow reasons that every man must become an enemy of his own country and that every country is an enemy of its own citizens. Nevertheless, he does not establish any causal link between both sentences. Even if one is linked to a country, countries are not persons. So, the fact that "my" country is related to other countries does not mean that I am. How to understand that governments, if armed, are willing to give their citizens to death just for their benefit? How to understand betrayal within the People's Common Sense?

Betrayal is a crime defined by the Constitution and consequently no one can be convicted of treason without the forced testimony of the witnesses or its own confession. The novel refers to the work of Nathaniel Weyl, Betrayal: The Story of Disloyalty and Betrayal in American History, pure controversy about what it means to be a good American or a bad one. Weyl, a writer and relevant economist in his time, is also well known for his conservative positions in the fifties, despite having recognized himself as a member of the Communist Party in the thirties (in 1939 he left the party), a young activist at Columbia University and a member of the self-appointed Ware Group, a cell of the Communist Party in Washington DC, linked with Soviet intelligence. Weyl became as well famous for testifying against Alger Hiss, a former left-wing colleague accused of spying in 1950, who was a State Department official and who was finally convicted for perjury in 1950 and sentenced to forty four months of imprisonment. 


\section{Betrayal is a crime} defined by the Constitution and consequently no one can be convicted of treason without the forced testimony of the witnesses or its own confession. 
The workers, the entrepreneurs, the students, the pioneer women, the minority groups... Those that are definitely least favored by the administration in each period, do not just rest meditating at home.

\section{THE ANGRY NATION}

The American system, which in its initial conception can be valued as meticulous, shows traces of change in the expression of criticism and the desire of self correction. So, somehow the good American is the one who shouts the clumsiness of the system and intends to straighten it. The workers, the entrepreneurs, the students, the pioneer women, the minority groups... Those that are definitely least favored by the administration in each period, do not just rest meditating at home. They express their frustration and anger at the lounge activism or in the street, through philanthropy or arts, with their voices and actions. The perception of this factor in the American society leads Charles Duhing -in a recent text for The Atlantic- to argue that America has always been an angry nation, and that unease and anger are classic trends in United States history. In the begining of the Revolution, the enormous discomfort against certain colonial habits of the English administration was expressed. Surely, disminishing the War of Independence to an effect of people's anger is an exaggeration that cannot be historically hold. But not because of its weakness as an historical cause, it is less certain that, in fact, the first revolutionary movements in the United States harbored much of popular helplessness and unease at the inflexible wall that was the British system.

It has been detected how disappointment, rage and even hate are conditioning the way of doing in American politics. A vibrant example has happened with the appointment of Judge Brett Kavanaugh as a member of the Supreme Court of Justice in 2018. Throughout all the procedure, attitudes of rage and histrionic rhetoric coming from defenders and detractors of the judge could be seen (Hemingway \& Severino). The breakup in public opinion was measured by the intensity with which goodnesses and evils of the candidate 
were shouted. The American authors handle the phenomenon of emotional support to a political candidate regarding people's frustration and resentment. But also, being it refered to more delicate issues at the heart of the process: for example, the brutalization of people in terrible childhoods or life traumas. Although not always for the better, the thought that collective anger can be a powerful lever for social change comes to mind. Anger -psychologists argue- is one of the clearest forms in people's communication because it broadcasts a lot of information about the individual. A 1977 study -at the University of Amherst, Massachusetts, suggested by James Averill- based on data from the Greenfield 18,000 inhabitants, the average American (if there exists an average American!) was shown in a permanent state of irritation and defensiveness. Everything seems to indicate that Americans have always been irritated by their political system, with which they remain angry or suspicious. In order to understand the collusion between personal anger and the social movements, social and scientific branches also point out that the phenomenon of

\section{The average American (if there exists an average American!) was shown in a permanent state of irritation and defensiveness.}

emotional voting in elections are due to frustration and resentment.Anonymous American's rage is a behaviour at which travelers, journalists and writers have paid attention. Recently, slogans such as "Jews will not replace us" or "White lives matter" have been heard, some others urging to defeat the "Fascist Liberal Democrats", the protesters on the street asking those enemies to be replaced in institutions by "people like God commands" (Nice Guys). These are the Alt-right movements pride on the white ethno nationalism and the socalled Western Civilization. But certainly neither the Alt-right movements nor Presidencies as the Donald Trump's have invented the use of anger to make politics. In the nineties, the American policy had in the Newt Gingrich -head of the Republicans in the House of Representatives and nominated to the Presidency for his party in 2012- a pioneer in the use of histrionics, rage, and even intimidating messages (Packer). 
About the current intimidating rhetoric, historians have seen some parallelism with several precedent states of affairs: for exemple in the 1850s (Freeman). Paradigmatic in this field, the thirties showed the world that the social rage that overflowed the codes, was also part of the American style. In the field of fiction, the book The Grapes of Wrath by John Steinbeck (1939) dived into the daily routine of universal issues such as war, totalitarianism, hunger, unemployment, despair... The anger exposed by Steinbeck was reduced to the substratum of proper names, experiences; it was tangible, human, much more real than the anger of the faceless people taken the Winter Palace in 1917. The dogma of American democracy was irrelevant to the starving Americans. Nor was there any interest in defending universal causes as the self-determination of the people and nations that were a target of discussion in the international interwar scene. Until reaching the narration of anger, Steinbeck had taken the path of despair in US. He covered -helped by the superb work of the photographer Dorothea Lange (Spirn) to whom the Government commissioned to make a photographic report between 1935 and 1936 (Quirke)- the crisis of farmers migrating on foot to California due to the effects of the Dust Bowl (Gregory). During the Depression famine and dust storms had primed with the agricultural population of the Midwest, in the states of Oklahoma, Kansas, Texas, Nebraska, South Dakota and Colorado. A wave of migrants, homeless people, itinerant ones of all ages, sex and condition, systematically moved westward, leaving behind them their belongings first, and then their lives. Children are born dead, grandparents pass away while walking, those who live starve themselves to death, the dignity of migrants is stunned by pain and fear, finally by absolute helplessness and shame. John Steinbeck describes the situation in seven articles for the San Francisco News. This work form a book entitled The Harvest Gypsies (Steinbeck 1936). Those immigrants who go to the "haciendas" -says Steinbeckare first used to serve the Californian agricultural industry, and then rejected: unnecessary ones, they become homeless. Even though in their pain, they are also hated by the local population: because they are dirty and ignorant, they bring diseases and insecurity.

The American optimism cracks when it comes to considering the behavior of power. When anger rises to the category of social fury and some kind of rebellion erupts, the offense of power to the people takes the form of a moral truth. Such situations have occurred in matters of race and civil rights, in the abolitionism during the first half of the nineteenth century (Harrold), or in the civil rights movement between the 1950s and 1970 s (Burrogh). Also in the anti-nuclear and environmental protection campaigns in the East and in California from the sixties to the eighties: transversal activisms regarding the ideological and social origin of the activists, even though the conservative media have characterized them as "liberal" or lefties movements. 
Most times American vote against an option, not in favor. One recent example has been carried out by the citizens opposing to Trumpism in the Mid Term, 2018. Anger is seen in the voter's reactions to state legislative elections in many occasions. A relevant percentage of the population considers this institution systematically harmful with their particular interests. Voting in anger is channeling through the vote the feeling of affront and the desire of revenge from policies that we believe to be harmful for us. Getting angry and showing myself as such is easier than deciding which option is the least attentive to my interests. But the anger vote usually gives ephemeral or pernicious results. In Carnegie Hall,February 1968, in reference to the radicalism that distilled people's fury,Martin Luther King addressed the audience warning that "being angry is not enough".

\section{HATE: PUBLIC LIMITED COMPANY}

Throughout contemporary history, popular anger takes its shape in groups and political parties whose purpose is to destroy the current system. Fascisms, dictatorships, cesarisms, authoritarianisms, etc. are usually the culmination of mass movement processes guided by populism -but not only this: revolutionary governments as well. Populism,

\section{Fascisms, dictatorships, cesarisms, authoritarianisms, etc. are usually the culmination of mass movement processes guided by populism.}

apart from the nuanced definitions handled by political scientists, is sometimes not so easy to discern. José María Lassalle (Lasalle) suggests that today there is a "sociological right" that lives "frightened by the cultural changes of the $21^{\text {st }}$ century" in addition to "a transverse apoliticism that brings together a multitude of discomforts against the hegemonic intellectual left". The fear of change and transversal apoliticism demand "moral order" and mostly a range of simpler political options. The sociological right would have experienced a deep discomfort with postmodern images: pluralism, heterodoxy, relativism, 
fragmentation, identities... This could be interpreted as a reprehensible expression of the prevailing disorder. Americans, following populism or sociological right, voted in 2016 with a large percentage in favor a candidate who, like them, felt excluded from the current system. However, "Trumpism" should not be considered as a historical exception; it founds its dogma on bringing the "plebs" to the very heart of the political regime obviating as much as possible the institutional intermediations of democracy, pretending to lighten the weight of the legislative power in favor of the executive. The leader "understands" the needs of the people and pretends to produce laws bypassing debate and consensus. This is not new, nor is it that populism flattens the intellectual horizon of citizens by nullifying their expertise to overcome the distance between what is wrong and what is right, what is morally reprehensible or what is not.

Once the political correctness has fallen, the abundance of media -mainly through social networks- and the speed with which messages are spread accelerate the transition to violent forms: without biting our tongues, without distance of reason and moderation, losing empathy and tolerance. When it is the group who defames or insults, this action becomes a powerful weapon that breaks coexistence. Maintaining the forms, the second half of the twentieth century society has raised taboos about some differences such as skin colour, clothing style, language, religion, sexual orientation... Sociological right-wing parties, brutalized, have expressed their disgust and immediacy in political action: steady hand beating the problems -most of them being not temporary and that cannot be solved through specific actions. The paradox is that the postmodern condition of immediacy is empowering the ideological profiles that precisely detest postmodernity. I will evoke that Trump's hand gesture underlining vigorously two words: "right now!"

The most recent American sociological right-wing party appeals to the fantasy of a world prior to the digital revolution, a recognizable place in history to the American hegemony. However this self-proclaimed party calls for a closed and clear order in which national facts can only be interpreted in the category of myths. The chimera shows the bluenecked America, the industrial America that imposes its patents and products on the rest of the world, coinciding with the more youthful stage of Trump's life: a man in his old age who resists recognizing the current world, and who makes no effort to empathize with that large portion of citizens who have not voted for him. The American Alt-right Movements surfaced a decade ago in local politics, and are by no means an updated form of American conservatism, which Dan T. Carter already analyzed in his book The Politics of Rage. George Wallace, the Origins of the New Conservatism, and the Transformation of American Politics (Carter). There is not a direct link between recent sociological right movements and more or less recent past radical conservatisms. The Alt-right emerged around 2008 mainly in postmodern sites like Twitter. The groups make use of social networks and television 


\section{The most recent}

American sociological right-wing party

appeals to the fantasy of a world prior to the digital revolution, a recognizable place in history to the American hegemony. 
channels to attract new members: both young people living in the virtual world and their grandparents who do not separate from television and who mishandle the Internet. Since its inception, they have been shaping their slogans taking the ongoing events as targets to harass: one day they it may be the Refugees from Syria, another one the Black Lives Matter movement, the feminist movements or the LGBTI activism. The Alt-right prides itself on the common ethno white nationalism and the so-called Western Civilization, but it should not be confused with a specifically Southern or Midwest expression: that of the angry impoverished people, separated by the system from all the goodness and benefits of their country. Each expression of the Alt-right has got its peculiarities, although all groups agree on the fact that the classical Republican Party does not represent their interests, and that it has betrayed them. The slogans shouted by the members of these groups in their public rallies and demonstrations do not express specific demands, only anger and resentment (Milburn \& Conrad), especially against those who are neither angry nor resentful.

No one has explained these movements -historically speaking- with the logic of changing the demographic and social configuration of the country. The American whites have lost positions in the control of the structures that manage power, and consequently they felt displaced, demoralized and "dispossessed" of the United States, a country they consider they have the right to rule. In fact, this perception has emerged cyclically in the country. As the extreme right movements did in the 1920s, these groups of outraged citizens proclaim the right to an insurgent activism, on the idea that the current political culture does not defend but hurts their interests, making them strangers in their own country. The Alt-right was accompanied by attitudes in favor of the self-defense rights, and the particular use of weapons invoking the Second Amendment of the Constitution. In colleges and university campuses -for example the riots in Charlottesville, in the state of Virginia (August 2017)- it was not unusual to hear young people chant frivolously: "Hail Trump,"'Hail our people” or “Hail victory!”. The documentary entitled Alt-right:Age of Rage, by Adam Lough (2018) is a credible account on the nature of this movement, whose name was coined in 2008 by one of its most popular leaders, Richard Spencer. Jared Taylor with his book Racial Consciousness in the 21th Century (2011) invokes the creation of an ethno racial state; or The American Renaissance magazine, now renewed into a website, which defends the idea of a white community pride.

After a decade of intense activism, analysts suggest that the Alt-right is declining due to internal divisions that make a dent in the strength of its actions. In addition, the arrival of answering groups, the Antifa or Antifascists, also has an impact on the supremacist movement. The American Antifa, inspired by the thirties anti-fascist movements in the Europe, has been object of attention in crucial foreign media such as The Guardian. The BBC Channel at the beginning of 2017 claimed that a battle between two opposed poles 
was taking place in the United States: Antifa V Alt-right (Yates), and the supremacist leader Spencer himself recognized that the Antifa was seriously undermining them. Both positions, Alt-right and Antifa, have reminded people of episodes that took place in the thirties and that nobody wanted to be reminded of. After the start of the Trump Presidency, supporters and detractors of the new president literally stuck in the street, and there were hundreds of detainees for their violent actions throughout the country.

With the citizenship severely divided, many analysts would rate the year of 2017 as one of the darkest eras remembered in the United States due to hate and violence (Roberstson). In short, as the analyst Fareed Zakaria warned in 2017, the Trump presidency lead to an emphasis of the social polarization. In a kind of little virtuous revival, citizens seem to seek their place in society by defining themselves through personal identity elements such as race, gender, sexual orientation... Wealth and poverty accompany these characterizations, but are not substantial when it comes to the understanding of the situation.In the last decade,Americans -especially young people-did not define themselves

\section{In the last decade. Americans -especially} young people- did not define themselves by a political choice. Social classes are no more clearly denoted. However, cultural distance between non-university rural space and university and professional urban elites can be observed.

by a political choice. Social classes are no more clearly denoted. However, cultural distance between non-university rural space and university and professional urban elites can be observed. The problem -as Zakaria pointed out- is that identity, culture, or creeds are not "reasonable" aspects, or a matter of negotiation and social commitment. The Administration could negotiate about material matters or economic differences, and agreements aimed at social peace. The investment in resources fitted the solutions in a range of possibilities from zero to ten. Satisfactory action plans could be achieved in the middle of this scale. But this is not possible when identity comes the matter of the negotiation. At this point, the positions have irreducibly developped. 


\section{IMAGES OF ANGER}

Over the decades, actions linked to social frictions have diversified their forms. Americans have for example burned their flag more often than we usually imagine if we take into account that this country displays a flag in every corner because US Americans love their colors. The constant dialogue between acceptance and rejection with this symbol is one of the symptoms of their identity. In the act of burning the American flag -protected by the right of free expression- a radical complaint which would be defined as anti-American was raised. In November 2016, after Trump's victory, at the sight of a country in hands of a leader considered by many people dishonest, quirky, liar and a lot of other nasty things, the streets of the United States were filled with frightened citizens. We recover the archives of the country's press editing images of large groups of people around a burning American flag. The staging of this national disgust was to attack the most efficient symbol of Americanism: the flag. This action expressed the feeling of disaffection and helplessness in which a remarkable part of nation find themselves after Trump's victory. The number of riots that included the vexation of the flag increased.

Students from Hampshire College, Massachusetts, withdrew the national flag of the institution, an example that was followed by other schools all across the country: "If my flag represents "this", it is no longer my flag: Shame on us!" The war of the flags spread like wildfire when the reaction of the groups considered the self-defenders of national symbols broke out. Some devastating slogans in the style that crowned the head of The Washington Post on November 9, such as "Democracy Dies in Darkness", helped to justify the "anti"outbursts. Defenders and critics with these angry actions invoked similar arguments. The triumphant America and the loser one reproached each other for the lack of morality and respect, as well as for behavior unworthiness. If for some individuals the Trump Presidency was moral and aesthetically ugly, for others the burning of the flag was dishonest, a treason to the nation. In both positions there was a kind of panic, but only the defenders of the sacred sense of the flag (Welch, 2000) above the individual right to free expression criminalized the protest actions of the losers at the polls. The United States has been an inspiring nation for the youth all over the world that, even if censoring the presence of the United States outside its borders, has imitated those rebel styles with which young Americans have fully engaged activisms against the system.

The Getty images archive keeps images of Americans of all ethnicity, gender, and condition rallying for the defense of civil rights (Speltz) and burning the symbols of the homeland. Burning flags was a national sport in the years of struggle between Unionists and Confederates; throughout the nineteenth century, the followers of political foes burned partisan flags. Some years later, in 1967 a United States flag was burnt in Central 
Park. And American pop art in the fifties -Jasper Johns (Israel)- used the flag at will. Later, in the eighties, the artist Dread Scott (remember that Dred Scott, without the "a" was the name of the slave who, in the 1850 s, took a pulse to the entire American legal system for the recognition of his free man condition), displayed an American flag on the floor of an exhibition asking the public what was the correct way to display a flag (1989, School of the Art Institute of Chicago) (Vile). The advertising companies that began to promote the products of modern America at the beginning of the twentieth century placed the (very colorful) flag on the product label, where they thought it would have a favorable effect on sales.

It is worth to recall that, on the matter of how and where the flag can be deployed, there is a protocol in the United States. This issue is so important that there is an extensive literature on the controversies about the misuse of the American flag. In his book, Burning the Flag: The Great 1989-1990 American Flag Desecration, Robert Justin Goldstein investigates the controversy that, between 1984 and 1990, went into Court. Eluding the details about the particular case of the flag burned in Dallas (1984), the fundamental question was whether to lash out against the flag was acceptable (and consequently legal) as a form of political protest. In 1989 the Supreme Court recognized that burning the flag constitutes a merely cultural act, a form of discourse and not a violent or a criminal gesture, thus giving arguments in favor of those who defended the right to express themselves according to the dictates of the culture of the protest.

\section{GUILTY, ASHAMED AND REDEEMED}

We are used to thinking that Americans approach to universal moral values from the peculiarity of the so-called American values. From this perspective, the US American "subjectivity" has won the battle to the universal values. But also, American history has revitalized a type of individual conscience that, tormented by shame (Stearns, Shame: A Brief History) and blame about the damage committed by administrations, seeks the way to promote empathy with the heirs of victims and tries to recompose the moral damage with current actions. The history of collective feeling of shame in the United States shows highs and lows. The illustrated revolution in America at the end of the $18^{\text {th }}$ century highlighted human dignity. Benjamin Rush stated that "it is universally recognized that shame is a punishment worse than death". Throughout the nineteenth century, the virtue of shame was abused, to the point that it acquired a relevant position in private space under the guidance of Puritanism, of course not in the field of public and institutional activities. The ominous slavery institution remained for a long time and, once done, the American nation preferred not to assume any kind of regret or shame. Afterwards, during the hightlights of 
the American project - the Gilded Age- self-confidence and arrogance prevailed.According to the scholars, in the splendid decades of Pax Americana -1940s and 1970s- the lowest levels in the citizenship tendency to feel shame were appreciated. Scholars stated that nevertheless, from the nineties, the American society would have significantly increased that feeling of shame. Nowadays, the Shame's Revival (Stearns, "Does American culture shame too much -or not enough?") suggests that US Americans discover a certain empathy with the harms of others, especially those related to the reprehensible actions of their ancestors.

Actually, the feeling of guilt and shame is perhaps more rooted in the Catholic culture than in the Protestant one. We perfectly know that Protestant ethics eludes both feelings, guilt and shame, when the damage emanates from actions over which the individual has no control. This is obvious in the case of the ominous past of the powers, which in the United States clearly refers to the original American populations, massacred or cornered in the Indians reserves during the 19th century. However, there is also a feeling of responsibility due to an unhealthy heritage, especially in response to

\section{American history has revitalized a type of individual conscience that, tormented by shame and blame about the damage committed by administrations. seeks the way to promote empathy with the heirs of victims and tries to recompose the moral damage with current actions.}

those government actions that injured human rights in their most universal aspects. This kind of attitude involves many US citizen activisms inside and abroad the country. This progressive activism (inspired by the thinking of the unnatural disorder or the world), that blamed of unethical the Administration actions, was known as Folk Politics. This activism rallied the criticism of the government's warmongering attitude or the bankruptcies of the constitutional legacy of civil rights. The term Folk Politics, which became very popular was coined by Nick Srnicek and Alex Williams to refer to a type of protest that, in their opinion, came ineffective to modify things. The protesters did not understand, they said, the real and complex nature of the problems that aroused them. Today, protest movements, continued Srnick and Williams, are isolated, without a logical structure or clear objectives 
of change in the style of those of the twentieth century. Somehow, the culture of the recent American protest resembles those of the last third of the nineteenth century. However, the atomization of critical movements within the country also manifests the style of doing things in the current times: fractured, if compared with those of the late twentieth century. The issue of inherited guilt (Pettigrove) -away in almost in most epochs of the history-sneaks into American public debates with more or less intensity depending on the nature of times. Attempts have been made to close the historical processes by requesting the forgiveness of the still alive victims, for example of Japanese-born Americans interned in camps during World War II (Presidente Reagan in the US Congress in 1988). This process was followed by an economic endowment of more than a billion and a half dollars to compensate the victims and their heirs. Furthermore, the responsibility for the extermination of the Indians has been a recurrent topic from the second half of the twentieth century onwards, having achieved some kind of recognition of the damage that, without satisfying the descendants of the victims, tends to close the issue. But it does not happen the same with slavery: a

Attempts have been made to close the historical processes by requesting the forgiveness of the still alive victims, for example of Japanese-born Americans interned in camps during World War II (Presidente Reagan in the US Congress in 1988).

wound is still open (Davis). In 1998, during a tour in Africa, President Clinton repeatedly apologized for the slave trade. But on Clinton rained all kinds of criticism in the United States: for apologizing in countries such as Uganda or Rwanda, which had not been a source of export of slaves to North America, for acting on the basis of the political interests of the United States in African countries, for not apologizing directly to the community of afro descendants in the United States, for not remembering that slavery was also then a plague in many areas of the African continent...

Certainly, for decades the black community in the United States has been demanding the recognition of inherited guilt and the subsequent reparations. In 2007 the Virginia legislature adopted a resolution of apology for slavery, which was followed by other historical slavery states: Arkansas, Florida, Connecticut, Maryland, New Jersey, and 
North Carolina. But most important, the Legislative Chambers passed resolutions asking for forgiveness about the role played in the slavery maintenance processes during the first decades of the 19th century. Of course, these acts of formal request for forgiveness have never been verified by any executive branch. The recent apology, during the presidential campaign in 2015, of the Democratic candidate Bernie Sanders, is surely the result of a virtuous ethic but also of a political opportunity. The important question is that it exemplifies the collective unavoidable feeling of guilt of an entire country. As a way to collective redemption, people are assuming the ominous ancient events they hardly know. Public actions intended to ask for forgiveness tend to deal with matters that do not correspond to the actions in question. For instance, Reagan apologized for the collective hysteria that took thousands of Japanese-American citizens in concentration camps, but he did not do so for the civilian deaths resulting from military actions during his tenure such as the nearly three hundred passengers of an Iranian flight who lost their lives due to a US missile. The Obama era (2008-2016) was the opportunity to address discursively the question of the recognition of the harms and to ask for forgiveness, but the geopolitical relevance was not alien to this peculiarity of the stage in question. On the contrary, Obama did not apologized in his visit to Japan in 2016 for the facts of annihilation of the civilian population because of the launching of nuclear bombs on Hiroshima and Nagasaki; the total amount of victims is unknown but it is thought to be about one hundred and fifty thousand people. Therefore, although with exceptions, the United States does not reconsider the political and military decisions taken in times of war, as Jennifer Lind explained in Sorry States: Apologies in International Politics.

In relation to individuals, the American citizen may offer finance and life in the service of humanitarian causes. It is observed that those citizens apologize for belonging to a country overflowing with resources, for feeling immensely favored by a fate that they believe they do not deserve, or for feeling the punctual vital restlessness unavoidable for people overwhelmed by everyday lacks and dangers. In a good novel published just over a decade ago, Returning to the Earth, the author, Jim Harrison, drew a character that is precisely the embodiment of the American unselfconfident but also capable of loading with all the negative actions of the American history. David is an apprehensive man who emerges from sadness to provide material supplies and devices, bought with his inherited assets, to those who illegally cross the Mexican and continue northward. But faith in the authenticity and sense of this humanitarian cause falls apart when David proves that, by integrating other activists into his project, a huge NGO emerges, and consequently, it becomes to work more efficiently, "in the American way", as a company. David feels defeated in his interest in correcting the global evil just by doing the right thing, by doing something good. 


\section{THE LEGACY OF DISENCHANTMENT}

Disenchantment, hopelessness, lack of faith in themselves... No one better than Americans to tell the great deception of the American dream. Pessimism is part of the tone in the American cultural legacy: the disaffection for the group to which one belongs, the self-destructive air of the characters, the warnings, the conspiracies and prophecies, the hidden organized crime, the insignificant heroes... Just a disgression. Despite the weight of this narrative tendency that underlines the disappointment, not Americans but Canadians are those who better embody the rhetoric of defeat and loss. This thesis is well developed in the work of Seymour Martin Lipset, Continental Divide. The Values and Institutions of the United States and Canada. American identity has incorporated the dogma that the country comes from the "winners": the uprising settlers against the English tyranny. Meanwhile the Canadians founded their country on the basis of the Legitimists loosers that fled to the northern British colonies, in Nova Scotia and New Brunswick.

Two classics with a very different literary profile, both Nobel Prizes for literature, give us solid examples of the cultural weight of American moral dejection. When in the early twentieth century Sinclair Lewis dared to denounce the very unimpressive daily life of the Midwest in his book Main Street, describing the abulia and the vital poorness, the public opinion understood he was little less than committing treason. Lewis had little success among the readers of his time, but nowadays we appreciate in the book the harsh exposure of purely American stocks, mistakenly imagining that the author radiographed Americanity in its purest state. Decades later, I turn again to the work of John Steinbeck, in this case with the title The Winter of Our Discontent (1960), which clearly expresses the feeling of helplessness in the face of the great lie of the American dream in the fifties. In the society portrayed by Steinbeck nobody and nothing is what it seems to be; money is the essence of each other's interest, immigrants cheat on the administration, vendors bribe for getting a customer, and even friends and siblings denounce each other in anticipation of a reward. Envy, jealousy, lies... all these impoverish the human quality of relations between relatives and comrades. Where is the social optimism that it used to be in America at the end of the Second World War? Where is the morality that corresponds to American democracy?

But in the same way that the American licks his wounds, he narrates the titanic efforts to get out of the hole, to overcome frustration and anger. Literally speaking, as if the attack on the Twin Towers in 2001 had been a transcript of Vesuvius eruption that took Pompeii and Herculaneum ahead, in the cultural images about the horror of $9 / 11$ we find out this idea of an inadequate and finalized world from whose ashes a different America will arise. The unjustifiable attack could also be seen as an opportunity to amend 
mistakes. In Jay Mclnerney's novel, The Good Life, the reconstruction of New York City from the attacks is proposed as a window, an opportunity to improve the unsatisfactory lifestyle of Manhattan people: the wasteful and obscene abundance conceived in the nineties. The feeling of rebellion implies becoming aware of oneself, in an intimate way first, then in comunity. And this critical, radical or delicate attitude, perhaps labelled as anti-American (Huguet), deeply differs from conventional regenerations.

In the disgust for the US America in progress, dystopia unfolds with many curious examples of the Americans self-critical attitude. I will just mention Colson Whitehead's book, Zone One. The central character in this book, named Mark Spitz, cleans the streets of Manhattan, and while doing so he goes back to the past. In that place there was an instant when human civilization jumped through the air -humanity as a whole, or humanity as the American civilization?, we may wonder. Immersed in self-pessimism, in White Noise (Don de Lillo) one can clearly see the critical feeling about what we have become. In De Lillo's story, the action takes place at the East Coast, in the north of New York. In this dystopia there is no longer a "clean" place in America where to take refuge from the environmental

\section{America does not work for everyone. because in fact it has never been of great use to those who could not know how to take advantage of it.}

catastrophe that lurks. When the average citizen contemplates the television screen, his attention is captured, says De Lillo, by a constant flow of words and images, graphics and particles. This image of America becomes even more devastating when De Lillo says that people suffer from cerebral wilting and predicts that a catastrophe is needed from time to time to interrupt the ceaseless bombardment of information. And all of that in 1985, when digital revolution had not appeared! A decade earlier, in 1976, Sydney Lumet directs Network (Itzkoff), a satire on the dark world of television. Being selected in 2000 for preservation in the National Filmography Registry, the movie presents the system -television- as corrupt, terrifying, and unforgiving. No one can emerge victorious from the contact with it. There is not a great difference with the Edgard Allan Poe's tales, which precisely subverted the triumphalist discourse of success and prosperity, of full selfconfidence in the ability of American society to transform itself (Tally). 
Finally, in the traditional national literature of losers and defeated since the Great Depression (Hearn), the United States is no longer a country of opportunity, a place that drives the ragged social foundations toward the tops of abundance and well-being. On the contrary, it is a stark country in which the best that can happen to those who arrive with their hands in their pockets is to realize in time that America deceives them, and to be in a hurry to return home.

To close this article, quoting Dos Passos in his Manhattan Transfer is perhaps to mention the evidence, a testimony that nevertheless continues being very useful to understand the self-criticism in America. In Dos Passos novel, the America imagined by migrants is just a postcard. The real America are the humiliating medical inspections before leaving the ship that takes us to its coasts, the devious officials we do not understand, the infected neighborhood near the port that, perhaps, we will never reach, the working hours -if there are jobs- demolishing people for unsatisfactory wages... America does not work for everyone, because in fact it has never been of great use to those who could not know how to take advantage of it.

\section{References}

Averill,J.R. Anger and aggression:An essay on emotion. New York: Springer-Verlag, 1982. Print.

Burrogh, B. Days of Rage: America's Radical Underground, the FBI, and the Forgotten Age of Revolutionary Violence. New York: Penguin Books, 2015. Print.

Carter, D. T. The Politics of Rage: George Wallace, the Origins of the New Conservatism, and the Transformation of American Politics.Baton Rouge, Louisiana: LSU Press, 2000. Print.

Clune, L. Executing the Rosenbergs: Death and Diplomacy in a Cold War World. New York: Oxford University Press, 2016. Print.

Coale, S. Ch. Paradigmas of Paranoia. The Culture of Conspiracy in Contemporary American Fiction. Tuscaloosa: The University of Alabama Press, 2019. Print.

Davis, A. M. "Apologies, Reparations, and the Continuing Legacy of the European Slave Trade in the United States". Journal of Black Studies. 45: 4. (2014): 271-286. Print.

De Lillo, D. White Noise. New York: Viking Press, 1985. Print.

Doctorow, E. L. The book of Daniel. New York: Random House, 1971. Print. Dos Passos, J. Manhattan Transfer. New York: Harper \& Brothers, 1925. Print.

Duda,J. If This Be treason: The American Rogues and Rebels Who Walked the Line Between Dissent and Betrayal. Connecticut: Guilford, 2017. Print.

Duhing, Ch. "The Real Roots of American Rage. The untold story of how anger became the dominant emotion in our politics and personal lives - and what we can do about it”. The Atlantic. January/February 2019. Print.

Freeman, J. B. The Field of Blood: Violence in Congress and the Road to Civil War. New York: Farrar, Straus and Giroux, 2018. Print.

García, 0.J. \& R. Magnútóttir. Eds. Machineries of Persuasion European Soft Power and Public Diplomacy during the Cold War. Berlin, Boston: Gruyter Oldenbourg, 2019. Print. 
Goldstein, R.J. Burning the Flag: The Great 1989-1990 American Flag Desecration. Kent: The Kent State University Press, 1996. Print.

Gregory, J. N. American Exodus. The Dust Bolwl Migration and Okie Culture in California. New York: Oxford University Press, 1989. Print.

Harrison, J. Returning to the Earth. New York: Grove Press, 2007. Print.

Harrold, S. American Abolitionism: its Direct Political Impact from Colonial Times into Reconstruction. Charlottesville: University of Virginia Press, 2019. Print.

Hearn, Ch. R. The American Dream in the Great Depression. Santa Barbara: Greewood Press, 1977. Print.

Hemingway, M. \& C. Severino. Justice on Trial: The Kavanaugh Confirmation and the Future of the Supreme Court. New York: Simon \& Schuster, 2019. Print.

Hofstadter, R. "The Paranoid Style in American Politics". Harper's Magazine. November 1964: 77-86. Print.

Huguet, M. "El americano antiamericano". The Conversation.com. 10 June 2019. Web.

Israel, S. M. Jasper Johns: Allegory of the American Flag. New York: Purchase College State, University of New York. Art History Board of Study, 2003. Print.

Itzkoff, D. Mad as Hell. The making of "Network" and the Fateful Vision of the angriest man in movies. New York: Henry Holt and Company, 2014. Print.

Jeong,S.Representing the Rosenberg case:Coover,Doctorowand the consequences of postmodernism. Seoul: Seoul National University,American Studies Institute, 1994. Print.

Lasalle, J. M. “Vox o la brutalidad política”. La Vanguardia. 19 January 2019. Print.

Lind,J. Sorry States: Apologies in International Politics. London: Ithaca, 2008. Print.

Lipset, S. M. Continental Divide. The Values and Institutions of the United States and Canada. New York: Routledge, 1990. Print.

Mclmerney, J. The Good Life. New York: Knopf, 2006. Print.

Milburn, M. A. \& S. D. Conrad. Raised to Rage: The Politics of Anger and the Roots of Authoritarianism. Cambridge: The MIT Press, 2016. Print.

Packer, G. The Unwinding. Thierty Years of American Decline. New York: Farrar Strauss and Giroux, 2013. Print.

Pettigrove, G. "Apology, Reparations, and the Question of Inherited Guilt", Public Affairs Quarterly. 17: 4. (2003): 319-348. Print.

Quirke, C. 'These Things Are a Pressin' on us': Dorothea Lange as Government Photographer, 1935-1936". Dorothea Lange, Documentary Photography, and Twentieth-Century America. Reinventing Self and Nation. New York: Routledge, 2019. Print.

Roberstson, A. "Alt-right: Age of Rage is a snapshot of one of 2017's darkest moments". The Verge. 14 March 2018. Print.

Sennett, R. "Lo gratuito conlleva siempre una forma de dominación". El País Semanal.18 August 2018: 47-51. Print.

Sennet, R. The culture of the New Capitalism. Connecticut: Yale University Press, 2006. Print.

Speltz, M. "An Activist's View of the Civil Right Movement". The iris behind the Scenes at the Getty. 26 October 2016. Web.

Spirn, A. W. Daring to Look: Dorothea Lange's Photographs and Reports from the Field. Chicago: The University of Chicago Press, 2008. Print. 
Srnicek,N. \& A. Williams. Inventing the Future: Postcapitalism and a World Without Work. London; New York: Verso, 2015. Print.

Starobin, P."The Angry American. Social rage as a measure of the country's moral and politica well-beign". The Atlantic.January/February 2004. Web.

Stearns, P. "Does American culture shame too much -or not enough?" The Conversation.com. 7 November 2017. Web.

---. Shame: A Brief History. Illinois: The Board of Trustees of the University of Illinois, 2017. Print.

Steinbeck, J. The Winter of Our Discontent. London: Penguin, [1960] 2008. Print.

---."The Harvest Gypsies". San Francisco News. 5-12 October. Print.

Tally, R. T. Jr. Poe and the Subversion of American Literature: Satire, Fantasy, Critique. London, New York: Bloomsbury, 2014. Print.

Vile,J.R. The American Flag: An Encyclopedia of the Star and Stripes in US history, Santa Barbara. Los Angeles: ABC-CLIO, 2018. Print.

Welch, M. Flag Burning: Moral Panic and the Criminalization of Protest. New York: Aldine de Gruyter, 2000. Print.

Weyl, N. Treason: The Story of Disloyalty and Betrayal in American History. Washington D.C.: Public Affairs Press, 1950. Print.

Yates, W. "America's extremist battle: antifa v Alt-right". BBC Trending. February 2017. Web.

Zakaria, F."EEUU ya es un país absolutamente polarizado... y ésta es la razón”. El GPS Global. El Confidencial. 26 June 2017. Print. 